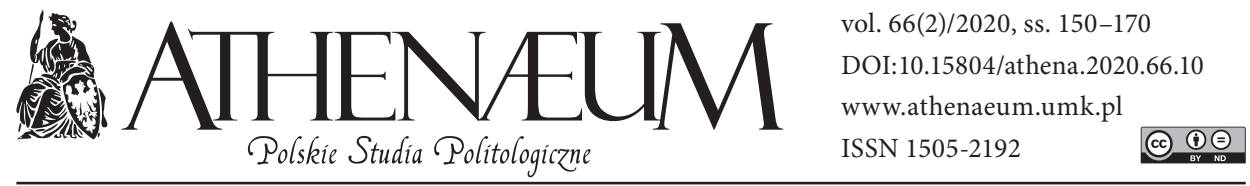

\title{
EDMUND BURKE: BEZPIECZEŃSTWO I POKÓJ EUROPEJSKI
}

\author{
EDMUND BURKE: EUROPEAN SECURITY AND PEACE
}

Paweł Hanczewski*

\begin{abstract}
ABSTRAKT
W XVIII wieku jeden z najczęściej dyskutowanych w Europie problemów z zakresu bezpieczeństwa i stosunków międzynarodowych dotyczył sposobów utrzymania pokoju. Dominowały trzy koncepcje: wiecznego pokoju, wojny sprawiedliwej oraz równowagi sił. Ważny głos w tej dyskusji zajął wybitny brytyjski myśliciel i polityk, Edmund Burke. Mimo że koncentrował on uwagę na sprawach wewnętrznych Wielkiej Brytanii i jej imperium, przez całą karierę publiczną interesował się też sytuacją na kontynencie europejskim. W przeciwieństwie do Rousseau, Kanta czy Vattela, połączył on wybrane elementy wszystkich trzech koncepcji. Przedstawił oryginalny pomysł na utrzymanie pokoju opartego na równowadze sił, prawie międzynarodowym i wspólnocie wartości łączących państwa europejskie, a wyrastających z dziedzictwa historycznego i kulturalnego.
\end{abstract}

Słowa kluczowe: bezpieczeństwo europejskie; wieczny pokój; wojna sprawiedliwa; równowaga sił; Edmund Burke

\section{- ABSTRACT}

Over the course of the $18^{\text {th }}$ century one of the most hotly debated issues in international politics concerned the means of preserving the general peace of Europe. There were three main concepts of how to achieve this aim: perpetual peace, just war, and the balance of power. One of the most interesting voices in the entire debate belonged to Edmund Burke. Despite the fact that Burke concentrated most of his attention on the internal situation of Britain and Britain's colonial possessions, he was also throughout his entire public career deeply interested in European politics. Unlike Jean-Jacques Rousseau, Immanuel Kant or Emer de Vattel, Burke combined certain elements of the above concepts. He formulated an original idea of European peace based on the balance of power, international law and cultural values derived from a common European heritage.

Keywords: European peace; perpetual peace; just war; balance of power; Edmund Burke

* Uniwersytet Mikołaja Kopernika w Toruniu, Wydział Nauk o Polityce i Bezpieczeństwie. 
W XVIII wieku kontynent europejski był areną licznych konfliktów militarnych, wśród nich wojen o sukcesję hiszpańską, austriacką, wielkiej wojny północnej, wojny siedmioletniej oraz tak dramatycznych wydarzeń jak rozbiory Polski. Część badaczy podkreśla ograniczony charakter tych wojen, prowadzonych za pomocą niedużych, zawodowych armii, i określa je jako „wojny władców” czy „ograniczone wojny” (Johnson, 2011, s. 191-196; Fuller, 1972, s. 15-25). Takie oceny są możliwe jednak tylko z punktu widzenia uprzemysłowionych i totalnych wojen dwóch następnych stuleci. Dla mieszkańców ówczesnej Europy były to wielkie i częste konflikty (Annual Register, 1762, s. 63). W rezultacie, w XVIII wieku znacznie częściej niż w poprzednich stuleciach dyskutowano na temat sposobów osiągnięcia pokoju bądź przynajmniej ograniczenia wojen (Anderson, 1993, s. 163-164, 219-220; Butterfield, 1966, s. 139-141; Sheehan, 1996, s. 97). Odwoływano się do trzech podstawowych koncepcji. Pierwsze dwie, wchodzące w skład „tradycji moralnych” cywilizacji Zachodu (Johnson, 1987, s. XI-XII), to idea „wiecznego pokoju” oraz wojny sprawiedliwej. Celem pierwszej było osiągnięcie trwałego pokoju poprzez stworzenie systemu bezpieczeństwa zbiorowego obejmującego, w zależności od wersji, większą, łącznie z posiadłościami tureckimi, bądź mniejszą, bez nich, część kontynentu europejskiego (Johnson, 1987, s. 176-177; Archibugi, 1992). Najbardziej ambitny plan przedstawił na początku wieku Charles Irénée, ksiądz de Saint-Pierre (Souleyman, 1941, s. 77-92; Johnson, 1987, s. 180-181; Blaszke, 2016), ale zbliżone pomysły wyszły także spod piór najznamienitszych myślicieli epoki, między innymi Rousseau'a i Kanta (Johnson, 1987, s. 185-198; Tuck, 2001, s. 206-207, 218-225; Marulewska, 2005). Druga koncepcja, nawiązująca do Grocjusza i jego rozważań nad ius in bello, której najbardziej znanym przedstawicielem w XVIII wieku był Emmerich de Vattel, zakładała, że wojny należy najpierw „ucywilizować” dzięki przyjęciu powszechnie akceptowanych reguł określających sposób ich prowadzenia, aby stopniowo poddać je kontroli ze strony prawa międzynarodowego i ograniczyć do minimum ich liczbę, czas trwania oraz negatywne skutki (Ruddy, F.S., 1969; Johnson, 1987, s. 200-209; Hurrell, 1996, s. 233-255; Boucher, 1998, s. 262-268; Tuck, 2001, s. 191-197; Keller, 2006, s. 29-36; Armitage, 2012, s. 163-168; Pitts, 2013). Do tych dwóch koncepcji należy dodać trzecią, najczęściej omawianą w trakcie XVIII wieku, równowagę sił (Anderson, 1993, s. 163; McKay, Scott, 1983, s. 211-212; Grobis, 2003). Mimo różnic zwolenników wszystkich koncepcji łączyły pewne elementy, na przykład myślenie o pokoju w skali kontynentu europejskiego. Zwolennicy „wiecznego pokoju” odwoływali się niekiedy do równowagi sił, traktowali prawo jako ważny instrument dla zachowania pokoju 
(Williams, Booth, 1996, s. 87), akceptowali też pogląd, że cel ostateczny można osiągnąć stopniowo, rozpoczynając od wprowadzenia zasad regulujących wojnę (Johnson, 1987, s. 179, 196-197; Buchner, 2017, s. 151). Zwolennicy ograniczenia wojny również odwoływali się do równowagi sił (Tuck, 2001, s. 194), dostrzegali zasadność kongresów pokojowych, jeden z ulubionych tematów wśród autorów prac o „wiecznym pokoju”, choć nie traktowali ich jako sposobu na likwidację wojen (Johnson, 1987, s. 201).

Wszystkie te koncepcje nie zapewniły jednak pokoju. Przyczyn takiego stanu można szukać w typowych dla wszystkich czasów różnicach między teorią i praktyką życia politycznego. Można je również znajdować w słabościach koncepcji, na co zwracano wówczas uwagę. Planom „wiecznego pokoju” zarzucano oderwanie od rzeczywistości, ponieważ pomijały tak ważny element stosunków międzynarodowych jak rywalizacja między państwami. Zarzucano im również, że stawiały sobie utopijny cel całkowitego wyeliminowania wojen. Wątpliwości pod adresem własnych pomysłów zgłaszał Rousseau (Johnson, 1987, s. 190-192; Tuck, 2001, s. 207), a Kant, pisząc o „wiecznym pokoju”, nie miał przecież wielkich nadziei na jego realizację, opisywał model idealny (Johnson, 1987, s. 193-194). W pierwszej części Metafizyki moralności, która ukazała się rok po publikacji pracy Ku wieczystemu pokojowi, w której przedstawił plan wiecznego pokoju, przyznawał państwom prawo do wojny prewencyjnej (Kant, 2011, s. 450). Koncepcja ograniczenia konfliktów zbrojnych poprzez regulacje prawne spotykała się z zarzutem, że w gruncie rzeczy akceptowała i legitymizowała wojny (Johnson, 1987, s. 200, 203; Hassner, 2013, s. 179; Buchner, 2017, s. 152, 164, 178). Równowaga sił była krytykowana na gruncie politycznym, ponieważ dzieliła państwa europejskie na różne kategorie, podważając ideę wspólnoty europejskiej, a ze względu na niestabilny charakter stosunków międzynarodowych mogła łatwo doprowadzić do wojen (Souleyman, 1941, s. 95, 130; Anderson, 1993, s. 179; Sheehan, 1996, s. 102-103). Krytykowano ją też na gruncie moralnym - miała służyć jako usprawiedliwienie egoistycznych dążeń państw, przede wszystkim wielkich mocarstw, które chciały zachować dominującą pozycję kosztem innych krajów (Anderson, 1993, s. 176-177; Wight, 1966, s. 168). W grę wchodziło też oczywiste pytanie praktyczne. Mimo powszechnej aprobaty ze strony pisarzy politycznych i polityków, zapis o konieczności zachowania równowagi sił znalazł się traktacie brytyjsko-hiszpańskim z 1713 roku, kończącym wojnę o sukcesję hiszpańską między nimi (Anderson, 1993, s. 163-164; Sheehan, 1996, s. 97-98, 104; McKay, Scott, 1983, s. 96), nie zagwarantował pokoju. Czy nie była zatem, podobnie jak dwie pozostałe koncepcje, wyłącznie konstrukcją teoretyczną? 
Wśród autorów piszących o pokoju europejskim znajdował się wybitny brytyjski myśliciel i polityk, Edmund Burke (1730-1797). W literaturze naukowej Burke przez długi czas był przedstawiany albo jako jeden z najważniejszych ideologów XIX wiecznego państwa liberalnego, albo jako twórca doktryny konserwatyzmu brytyjskiego. Różnice zdań między uczonymi były tak duże, że pojawiły się opinie, iż Burke zmieniał poglądy w zależności od rozwoju sytuacji, w związku z czym nie można mówić o ich spójności. Pojawił się też pogląd, że było „dwóch Burke’ów”: wczesny i liberalny oraz od, rewolucji francuskiej, późny i konserwatywny. W ostatnich latach sądy te zanegowano, co wskazuje przede wszystkim na ciągle bardzo duże zainteresowanie życiem i dorobkiem intelektualnym Burke’a oraz na nowe możliwości interpretacyjne (Hanczewski, 2017). Jedną z konsekwencji jest rozwój badań nad tymi obszarami aktywności Burke’a, które przez długi czas pomijano. Wśród takich obszarów znajdują się jego poglądy na temat sytuacji międzynarodowej. Mimo że pierwszy artykuł na ten temat ukazał się w roku 1966, to większa liczba prac pojawiła się dopiero w latach 80. i 90. XX wieku (Wight, 1966, Why ...?; Vincent, 1984; Harle, 1990). Szczególne znaczenie mają opracowania profesora Davida Bouchera i kanadyjskiej badaczki Jennifer M. Welsh, która podjęła udaną próbę przedstawienia poglądów Burke’a w kontekście współczesnych teorii stosunków międzynarodowych: realizmu, idealizmu i rewolucjonizmu (Boucher, 1991; Boucher, 1998; Welsh, 1995; Welsh, 1996; Fidler, Welsh, 1999, s. 37-56; Welsh, 2013). Badania te nie są formą prezentyzmu historycznego, wskazują raczej na bogactwo myśli Burke’a. To, że nie zawarł on swoich poglądów w jednym traktacie, nie powoduje, że są one pozbawione wartości teoretycznej. Ta sama uwaga dotyczy faktu, że Burke wypowiadał się na temat stosunków międzynarodowych w reakcji na bieżące wydarzenia - o pokoju europejskim pisał, gdy pojawiało się dla niego zagrożenie, podobnie było z równowagą sił. Sformułowane w ten sposób opinie stanowiły integralny element poglądów Burke’a i mogą mieć uniwersalny charakter, wykraczając daleko poza jednostkowe wydarzenia. Jak zauważył jeden z badaczy: „Prace Burke’a na temat rewolucji francuskiej... dotyczą ogólnego problemu rewolucji, nie tylko rewolucji w Europie w XVIII wieku" (Vincent, 1984, s. 205).

Mimo wysokiego poziomu naukowego ustalenia badaczy opierają się przede wszystkim na analizie wystąpień Burke’a z ostatniego etapu działalności publicznej, od wydania w listopadzie 1790 r. jego najbardziej znanego dzieła: Rozważania o rewolucji we Francji. W niniejszym artykule chciałbym wyjść poza te ograniczenia czasowe i przedstawić poglądy Burke’a na temat pokoju europejskiego 
wyrażane w trakcie jego całej aktywności publicznej. Chciałbym także wskazać na najważniejsze podobieństwa i różnice między myślą Burke’a i wspomnianymi na początku dwoma „tradycjami moralnymi”. Ostatnie zadanie jest o tyle trudne, że zakłada spójność i stałość poglądów wśród ich zwolenników. Jak zauważyłem, niekiedy korzystali z opinii łączonych z odmienną tradycją, niekiedy zajmowali stanowisko, które stało w sprzeczności z ich wcześniejszymi sądami. Problemy te dobrze oddaje tytuł jednej z części artykułu dotyczącego przemyśleń Kanta na temat sytuacji międzynarodowej: Kant: Categorically Opposed to Intervention and Regime Change - Or Was He? (Hassner, 2013, s. 184). Dodatkowego kłopotu nastręcza fakt, że prawo międzynarodowe, do którego odwoływali się zwolennicy obydwu „tradycji moralnych”, było w XVIII wieku zlepkiem różnych koncepcji (Hampsher-Monk, 2005, s. 66-67). Znajdowało się na etapie tworzenia, nie należy spoglądać na nie jako na zestaw określonych reguł, które powszechnie akceptowano.

Początek kariery publicznej Burke’a łączy się z wydaniem w 1756 r. pracy Obrona społeczeństwa naturalnego (A Vindication of Natural Society). W tym samym roku rozpoczęła się wojna siedmioletnia, w trakcie której Wielka Brytania pozbyła się francuskiej konkurencji w Indiach i w Kanadzie. Zakończenie działalności przypadło na rok 1797 i wojny z rewolucyjną Francją. Między tymi datami miała miejsce wojna o niepodległość Stanów Zjednoczonych i rozbiory Polski, nie wspominając o niepokojach wewnętrznych w poszczególnych państwach europejskich. Całe dorosłe życie Burke’a upłynęło w cieniu konfliktów międzynarodowych i, co istotne dla zrozumienia jego poglądów w tej kwestii, także konfliktów wewnętrznych.

Zainteresowanie Burke'a sytuacją na kontynencie europejskim wiązało się z pytaniem, w jaki sposób osiągnąć i utrzymać pokój. Opisy działań zbrojnych i dyplomatycznych zamieszczane przezeń w czasopiśmie Annual Register, które redagował w latach 1758-1764, nie służyły wyłącznie zaspokojeniu ciekawości odbiorców. Podobnie było w kolejnych latach, łącznie z ostatnim okresem aktywności Burke’a, który przypadł na rewolucję francuską. Takie podejście odpowiadało perspektywie, którą przyjmował, pisząc o sytuacji w Wielkiej Brytanii i w jej imperium, ale też o wydarzeniach w poszczególnych państwach europejskich. We wszystkich przypadkach chodziło o to, w jaki sposób sprawować władzę polityczną, aby zapewnić bezpieczny rozwój państw i społeczeństw (Hanczewski, 2018, s. 69-77). Wbrew opiniom, że Burke był krytykiem swojej epoki i wrogiem Oświecenia (Clark, 2007), bardzo pozytywnie oceniał rozwój materialny oraz intelektualny, których był świadkiem (Annual Register, 1764, s. 2; 
Correspondence, 1968, s. 387; Bourke, 2012, s. 27-28). Pragnienie zapewnienia bezpiecznego rozwoju nie oznaczało jednak odrzucenia przemocy w stosunkach międzynarodowych bądź wewnętrznych. W niektórych przypadkach Burke uważał rozwiązania siłowe za jedyny właściwy sposób postępowania. (Annual Register, 1766, s. 14-15; Burke, 1994, s. 42; Fidler, Welsh, 1999, s. 50-51). Podobieństwo perspektyw pozwala na odwoływanie się do jego poglądów dotyczących sytuacji wewnętrznej w trakcie analizy jego poglądów na temat sytuacji europejskiej. Stały powód zainteresowania sytuacją międzynarodową nie musi jednak zakładać stałości poglądów Burke’a. Warto zastanowić się, czy poglądy miały taki charakter w trakcie jego całej kariery, czy też ulegały modyfikacjom wraz ze zmieniającymi się warunkami i upływem czasu.

W sposób typowy dla większości współczesnych sobie autorów Burke myślał o Europie w kategoriach wspólnoty (Butterfield, 1966, s. 142; Anderson, 1993, s. 157-158, 176; Sheehan, 1996, s. 101) i miało to duże znaczenie dla jego koncepcji pokoju. Pokój musiał mieć charakter ogólnoeuropejski, nie mógł istnieć tylko w jednej czy dwóch częściach kontynentu. W każdej chwili mogło pojawić się dlań zagrożenie ze względu na rozwój wypadków na pozostałych obszarach (Annual Register, 1759, s. 2-3; Annual Register, 1762, s. 14). Pisząc o poglądach Burke'a na temat Europy, badacze chętnie przywołują jego uwagi na temat „wielkiej wspólnoty chrześcijańskiej” czy Europy jako „faktycznie jednego wielkiego państwa" (Burke, 1991, First..., 237, 248), w których odwoływał się do Europy jako wspólnoty kulturowej. Jednak określenia te pojawiły się w pracach powstałych w roku 1796, krótko przed jego śmiercią, co prowadzi do pytania, w którym momencie Burke przyjął pogląd o dziedzictwie cywilizacyjnym jako fundamencie systemu europejskiego. Czy było tak „od zawsze”, czy też sięgnął po koncepcję Europy jako wspólnoty kulturowej ze względów krótkoterminowych, aby uzasadnić wojnę przeciwko rewolucyjnej Francji, skoro nie mógł znaleźć dla niej usprawiedliwienia w prawie międzynarodowym (Hampsher-Monk, 2005)? Takie określenia jak „system europejski” czy „ogólny system” pojawiły się we wczesnych pracach Burke'a (Annual Register, 1759, s. 2, 45; Annual Register, 1762, s. 2, 13). Nawet jeśli nie sięgał po nie bezpośrednio, to wielokrotnie podkreślał bliskie relacje łączące państwa europejskie. W trakcie wojny siedmioletniej wskazywał na związek między działaniami dyplomatycznymi w różnych częściach kontynentu dla przywrócenia pokoju powszechnego. Przy okazji sporów o obsadę tronu polskiego po śmierci Augusta III zauważył, że wybór króla stanowi za każdym razem „jeden z najważniejszych obiektów zainteresowania najpotężniejszych państw Północy”, a elekcyjny charakter monarchii „często prowadził do przelewu 
krwi i chaosu w dużej części Europy" (Annual Register, 1763, s. 44). Po rozbiorze Polski w 1772 roku stwierdził, że jest to akt o pierwszorzędnym znaczeniu, także dla państw położonych w odległych częściach kontynentu (Annual Register, 1772, s. 3).W pierwszych miesiącach rewolucji francuskiej zauważył, że bezpieczeństwo Wielkiej Brytanii jest uzależnione od równowagi sił w Europie, a ta z kolei od sytuacji wewnętrznej Francji (Correspondence, 1967, s. 106). We wszystkich tych przypadkach Burke odnosił się do systemu europejskiego jako wspólnoty państw związanych interesami politycznymi i gospodarczymi (Annual Register, 1772, s. 2). Nie oznacza to jednak, że zaakceptował pogląd o wspólnocie kulturowej jako fundamencie wspólnoty politycznej dopiero w ostatnich latach życia. Dużo wcześniej zwracał uwagę na wspólnotę wartości między Wielką Brytanią i mieszkańcami jej kolonii w Ameryce Północnej, przypisując im dalece większą rolę niż jakimkolwiek więzom politycznym, prawnym czy ekonomicznym. W roku 1775 mówił w parlamencie brytyjskim: „Tak długo jak będziecie potrafili utrzymać niezawisły autorytet tego kraju jako sanktuarium wolności i świątyni poświęconej naszej wspólnej wierze, gdziekolwiek wybrany naród i synowie Anglii będą czcić wolność, skierują swoje twarze w tę stronę... Jeśli odmówicie im udziału w tej wolności, zerwiecie jedyną więź, która pierwotnie utworzyła i nadal musi podtrzymywać jedność imperium... To duch angielskiej konstytucji napełniający tę potężną masę przenika, karmi, jednoczy, pokrzepia i ożywia każdy zakątek tego imperium aż po jego najmniej znaczącego członka" (Burke, 2012, s. 137). Taki sposób rozumowania nie był wówczas niczym wyjątkowym. Kilka lat wcześniej Edward Gibbon stwierdził, że Europa jako wspólnota opiera się na „ogólnym podobieństwie religii, języka i manier” (Hurrell, 1996, s. 246). Milczenie Burke’a na temat Europy jako wspólnoty wartości można wyjaśnić tym, że przez długi czas nie widział potrzeby poruszania tematu. Do rewolucji francuskiej państwa europejskie akceptowały pewne podstawowe wartości. Nawet pierwszy rozbiór Polski, który określił jako „bardzo poważne naruszenie współczesnego porządku europejskiego” (Annual Register, 1772, s. 2), nie stanowił zagrożenia dla Europy jako wspólnoty kulturowej. Rozbiór naruszał równowagę sił, na której opierał się pokój europejski, ale nie zagrażał podstawom cywilizacji europejskiej: chrześcijaństwu, rządom monarchicznym, prawu rzymskiemu i zwyczajom ukształtowanym w średniowieczu. Dopiero rewolucyjna Francja podjęła próbę zbudowania porządku opartego na całkowicie odmiennych zasadach i stąd coraz częstsze odwołania Burke’a do wspólnych wartości.

Spośród wspomnianych „tradycji moralnych” cywilizacji Zachodu, najłatwiej wskazać na różnice między Burkiem a zwolennikami „pokoju wiecznego”. Dla 
Burke’a była to jeszcze jedna abstrakcyjna teoria, która nie opisywała rzeczywistości, lecz postulowała stan, który był niczym więcej jak efektem spekulacji intelektualnych. Świat bez wojen nigdy nie istniał i mógł powstać tylko w umysłach ludzi, których określił mianem „rzekomych filozofów obecnej doby” (Burke, 1994, s. 173). Takie teorie uważał za najgorszego przewodnika w dziedzinie polityki (Burke, 1994, s. 75). Kolejna różnica wynikała z przekonania, że polityka, zarówno w wymiarze wewnętrznym, jak i zewnętrznym, jest dynamicznym procesem. Poszukiwanie rozwiązań, które gwarantowałyby określony stan „raz na zawsze”, na przykład w postaci „wiecznego pokoju”, było pozbawione sensu. Kolejna różnica dotyczyła stosunku do wojny. Zwolennicy „wiecznego pokoju” uznawali, że każda wojna jest zła i dążyli do jej eliminacji jako zjawiska, nawet jeśli miało to nastąpić w bardzo odległej przyszłości (Johnson, 1987, s. 181-183, 187-190, 194; Buchner, 2017, s. 152, 164, 178). Burke nie tylko godził się z koniecznością wojny, ale w pewnych sytuacjach do niej nawoływał. Ta niezgodność wynikała z różnicy poglądów na temat ludzkiej natury. Kant zakładał, że istnieje postęp moralny, dzięki któremu można ulepszać naturę człowieka, co ostatecznie miało doprowadzić do „wiecznego pokoju” (Williams, Booth, 1996, s. 80-81, 92-95; Hassner, 2013, s. 189). Burke przyjmował, że natura człowieka jest niezmienna. Jej ważnymi elementami były „namiętność i zawiść” (Annual Register, 1772, s. 3), z których początek brały wszystkie wojny. W takiej sytuacji wojen nie można było wyeliminować: „Jakkolwiek jest to godne ubolewania, wojny są nieuchronne w każdym stanie ludzkiej natury, można je odwlekać, ale nie da się ich całkowicie unikać” (Annual Register, 1772, s. 3).

Różnice opinii na temat wojny prowadziły do odmiennych zdań na temat pokoju. Podobnie jak dla Rousseau i Kanta, miał on dla Burke’a wielką wartość, jednak pojawiało się pytanie o to, jakiego rodzaju pokój jest możliwy do osiągnięcia. Pokój wieczny czy pokój nietrwały? W trakcie wojny siedmioletniej Burke pisał o „pokoju doskonałym” (Annual Register, 1761, s. 2), była to jednak bardzo odległa propozycja od „pokoju wiecznego”. Burke wyróżnił dwie sytuacje, w których dochodzi do zawarcia pokoju. Pierwsza, którą nazwał sytuacją „równości”, to taka, gdy żaden z uczestników konfliktu nie odnosi korzyści bądź wszystkie strony są w podobnym stopniu wyczerpane wojną. Druga sytuacja, „konieczności”, ma miejsce, gdy jedna ze stron odnosi wyraźne zwycięstwo, narzucając korzystne dla siebie warunki pokoju. „Pokój doskonały” pojawia się tylko w pierwszej sytuacji. Ponieważ żadna ze stron nie odnosi wyraźnego zwycięstwa i związanych z tym korzyści, warunki pokoju są równe dla wszystkich. Dzięki temu pojawia się możliwość, że pokój będzie trwał przez dłuższy czas. 
Natomiast pokój narzucony przez zwycięzcę jest zarzewiem następnej wojny, pokonany będzie dążył do jego rewizji (Annual Register, 1761, s. 2, 13). Przykładem takiego pokoju był pokój kończący wojny między Austrią i Prusami o Śląsk podczas wojny o sukcesję austriacką. W zdecydowanym zwycięstwie Prus Burke widział źródło konfliktu między tymi państwami w ramach wojny siedmioletniej, stwierdzając, że Fryderyk II po zawarciu w maju 1762 roku przez Rosję pokoju z Prusami i oddaniu korpusu rosyjskiego pod swoje dowództwo powinien zabiegać o utrzymanie istniejącej równowagi sił w cesarstwie. Jej naruszenie, zarówno kosztem Prus, jak i na korzyść Prus, uznał za najgorsze rozwiązanie, ponieważ w sposób nieuchronny prowadziłoby to do kolejnej wojny (Annual Register, 1762, s. 54-55). Jednak nawet „pokój doskonały” nie miał permanentnego charakteru. Wszystko, co zdaniem Burke’a można osiągnąć, to nietrwały pokój, o który należy bezustannie zabiegać. Obok niezmiennych cech ludzkiej natury, które nie pozwalały wyeliminować wojny, wynikało to $\mathrm{z}$ anarchicznego i równocześnie przypadkowego charakteru stosunków międzynarodowych. Jak zauważył w odniesieniu do relacji między Austrią i Prusami, uległy one znacznej poprawie po roku 1763 „przez jedno z tych niezwykłych poruszeń ludzkiego umysłu, których nie da się ani przewidzieć, ani uczynić za nie nikogo odpowiedzialnym i przez jedną z tych niespodziewanych zmian, które niekiedy dotyczą wszystkich ludzkich spraw" (Annual Register, 1772, s. 4). Sposobem zapewnienia chwiejnego pokoju było utrzymanie równowagi sił, co wymagało niekiedy wojny. Burke posunął się o jeszcze jeden krok, uznając niektóre działania polityczne mające na celu utrzymanie pokoju za większe zagrożenie dla pokoju niż wojna. Chodziło o takie działania, które pozwalały uniknąć konfliktu zbrojnego w krótkiej perspektywie, stanowiąc równocześnie źródło znacznie poważniejszych wojen w przyszłości. Przykładem pierwszy rozbiór Polski, kiedy to „kupiono obecny pokój za cenę przyszłego bezpieczeństwa”. Taką postawę określił jako „najbardziej poniżające i nikczemne tchórzostwo" (Annual Register, 1772, s. 3). Podobne stanowisko zajął w trakcie rewolucji francuskiej. Podjęta jesienią 1795 roku przez premiera Williama Pitta młodszego inicjatywa pokojowa spotkała się z jego miażdżącą krytyką. Pokój oznaczałby tylko odłożenie w czasie nieuchronnego konfliktu, w którym stawką było istnienie niepodległych państw i cywilizacji europejskiej (Burke, 1991, Second..., s. 290).

Pogląd o nieuchronności, a nawet konieczności wojny w określonych sytuacjach zbliżał Burke’a do zwolenników koncepcji wojny sprawiedliwej (Johnson, 1987, s. 201-202), z dorobku których, przede wszystkim Vattela, korzystał (Hampsher-Monk, 2005). Jednak w przeciwieństwie do nich nie widział 
prawa międzynarodowego jako skutecznego narzędzia ograniczającego wojny. Zdawał sobie sprawę z chaotycznego charakteru takiego prawa i wybiórczego traktowania go przez państwa, które dokonywały jego całkowicie dowolnej interpretacji, kierując się ostatecznie własnymi interesami. Zwrócił uwagę na ten element w trakcie wojny siedmioletniej, pisząc o sporach między Francją i Wielką Brytanią na temat zwrotu mienia zagarniętego między rozpoczęciem działań zbrojnych a wypowiedzeniem wojny. Mimo że dyplomaci francuscy powoływali się na zasady prawa międzynarodowego potwierdzone w traktatach pokojowych w Utrechcie (1713 r.) i Akwizgranie (1748 r.), Londyn, który był stroną tych porozumień, odrzucił taką argumentację. Burke podsumował sprawę krótko: „Jak zwykle, tymi kwestiami przerzucano się z wielką pasją i znikomym rezultatem" (Annual Register, 1761, s. 40). Stanowisko to powtórzył w roku 1772, pisząc o „nieskuteczności traktatów, gwarancji i sankcji” (Annual Register, 1772, s. 1) oraz w trakcie rewolucji francuskiej, gdy stwierdził: „Przykładamy zbyt dużą wagę do traktatów i umów” (Burke, 1991, First..., s. 247). Z podobnej perspektywy spoglądał na prawo wewnętrzne, oceniając je nie ze względu na treść, ale skuteczność. Na przykładzie Rzeczpospolitej wskazał, że nawet najlepsze prawo gwarantujące wolność religijną, a wyrażał się o nim bardzo pochlebnie, pozostaje fikcją, jeśli rządzący nie chcą go przestrzegać (Annual Register, 1767, s. 14,17-27). W rezultacie Burke traktował prawo nie jako zestaw reguł, którymi państwa powinny kierować się w relacjach międzynarodowych - taki pogląd przyjmowali zwolennicy wojny sprawiedliwej (Johnson, 1987, s. 201) - lecz jako jedno z teoretycznych uzasadnień dla ochrony równowagi sił.

Stosunek Burke’a do równowagi sił w wymiarze międzynarodowym był wysoce skomplikowany. Mimo że chętnie podkreślał swoje praktyczne podejście do polityki, to odnosił się także do teoretycznych aspektów równowagi. Uważał ją za element konieczny dla rozwoju kontynentu europejskiego i zachowania jego przewagi nad pozostałymi częściami świata. W jej braku upatrywał główny powód upadku kwitnących niegdyś ośrodków cywilizacji w Azji (Annual Register, 1772, s. 2). Podkreślał znaczenie posiadłości kolonialnych dla potęgi państw europejskich, było to jedno z głównych uzasadnień dla brytyjskiej obecności w Indiach (Annual Register, 1764, s. 34; O’Neill, 2016, s. 27, 32), i ich pośredni wpływ na równowagę europejską, ale poza takimi, dość często wyrażanymi przez innych autorów poglądami (Anderson, 1993, s. 170-174), tematu nie rozwinął. Zdobył się jedynie na uwagi, że państwa europejskie dążyły do równowagi sił w posiadłościach zamorskich (Annual Register, 1761, s. 5; Burke, 1991, Second..., s. 275) oraz że Brytyjczycy powinni kierować się tą samą zasadą w Indiach, 
równoważąc interesy lokalnych władców i wyznawców odmiennych religii (Burke, 1981, s. 115) ${ }^{1}$. Uznał, że równowaga sił pojawiła się samoczynnie na drodze rozwoju historycznego, a czas jej powstania określił albo na „wcześniejsze wieki" (Annual Register, 1760, s. 2), albo twierdził, że była obecna w polityce europejskiej „we wszystkich czasach” (Burke, 1991, Third..., s. 338). Dużo większe znaczenie dla zrozumienia jego koncepcji pokoju mają rozważania na temat celu równowagi sił. W XVIII wieku dominowały dwa poglądy. Zgodnie z pierwszym, zadaniem równowagi sił było utrzymanie równowagi między najsilniejszymi państwami, a jeśli jedno $\mathrm{z}$ nich sięgało po zbyt wielką potęgę, uzasadnione było rozpoczęcie wojny przeciwko niemu. W takim ujęciu równowaga sił mogła posłużyć jako usprawiedliwienie dla konfliktów zbrojnych (Sheehan, 1996, s. 102) i, jak zauważyłem, spotykała się z tego względu z krytyką. Zgodnie z drugim poglądem celem równowagi sił było utrzymanie pokoju europejskiego (Anderson, 1993, s. 163-164). Burke zajmował stanowisko wkraczające poza ten prosty podział. Z jednej strony uważał, że równowaga sił powinna służyć zachowaniu pokoju, przy czym na równowagę sił miały wpływ wszystkie państwa europejskie, również te, które były ofiarami polityki wielkich mocarstw. Przykładem Rzeczpospolita, którą uważał za kraj pogrążony w anarchii i całkowicie zdominowany przez sąsiednie państwa (Annual Register, 1763, s. 43-48). Zagarnięcie części jej terytorium w roku 1772 przez Rosję, Austrię i Prusy stanowiło jego zdaniem bardzo poważne naruszenie równowagi sił. Zwiększało ich potencjał, a Prusom dało także możliwość rozwoju handlu morskiego, co z kolei mogło zagrozić pozycji Wielkiej Brytanii jako potęgi morskiej i handlowej (Annual Register, 1772, s. 5-6; Correspondence, 1960, s. 310). Wpływ na równowagę sił w skali kontynentu przypisywał też lokalnym równowagom sił. W trakcie wojny siedmioletniej pisał o „równowadze Niemiec” zależnej od układu sił między Austrią, Prusami oraz Francją (Annual Register, 1762, s. 55). Temat rozwinął podczas rewolucji francuskiej. Wyróżnił wówczas cztery obszary funkcjonowania równowagi sił: „wielką środkową równowagę", obejmującą Wielką Brytanię, Francję i Hiszpanię, równowagę Północy, wewnętrzną i zewnętrzną równowagę Niemiec oraz równowagę Włoch, które łącznie składały się na „ogólną równowagę" europejską (Burke, 1991, Thoughts..., s. 349-351; Burke, 1991, Third..., s. 338-339). Zda-

1 Burke zwracał bardzo dużą uwagę na to jak sytuacja w koloniach, szczególnie w Indiach, może wpłynąć na sytuację wewnętrzną Wielkiej Brytanii. Obawiał się, że napływ bogactwa z Indii i przeniesienie tamtejszych metod rządzenia mogą doprowadzić do degeneracji całego systemu politycznego, patrz: Burke, 2015, s. 629-675. 
niem Burke’a równowaga sił pierwotnie przyczyniała się do ochrony „pokoju i wolności Europy”, jednak bardzo szybko stała się źródłem konfliktów i taka sytuacja utrzymywała się również w drugiej połowie XVIII wieku. Pisał o tym w bardzo krytyczny sposób: „Równowaga sił, chluba współczesnej polityki... jest przyczyną licznych i bezowocnych wojen" (Annual Register, 1760, s. 2; Annual Register, 1772, s. 2-3). Równocześnie jednak dopuszczał możliwość prowadzenia wojny, jako argument wykorzystując konieczność zachowania równowagi sił. Takie stanowisko zajął przy okazji pierwszego rozbioru Polski, aktu uzasadnianego przez państwa zaborcze pragnieniem utrzymania równowagi sił (McKay, Scott, 1983, s. 228; Serejski, 2009, s. 112-113). Burke odrzucał ten pogląd, jeśli nawet rozbiór pozwolił zachować równowagę między Austrią, Prusami i Rosją, to zagroził równowadze w skali całego kontynentu (Annual Register, 1772, s. 6). W roku 1773 stwierdził, że Wielka Brytania i Francja powinny połączyć swe siły przeciwko państwom rozbiorowym i, w razie konieczności, zdecydować się na wojnę (Correspondence, 1960, s. 429). Ostatecznym celem takiej wojny nie byłoby jednak przywrócenie równowagi sił, lecz zachowanie pokoju. Obawiał się, że podział ziem Rzeczpospolitej to pierwszy krok na drodze do dalszej ekspansji, następnym będzie otwarta agresja militarna usprawiedliwiona kolejny raz pragnieniem zachowania równowagi sił. W liście do posła pruskiego w Dreźnie, Adriana Heinricha von Borcke, pisał: „Co nastąpi później, drogi Panie? Państwa te [mocarstwa rozbiorowe] pozostaną potęgami wojskowymi, a ich armie muszą znaleźć zatrudnienie. Polska była tylko śniadaniem, a trudno znaleźć wiele podobnych jej krajów. Gdzie zjedzą obiad?” (Correspondence, 1960, s. 514). Przywrócenie równowagi między najpotężniejszymi mocarstwami, nawet za cenę wojny, było uzasadnione ze względu na pokój. Pokój nie mógł istnieć bez „wolności”, która w tym przypadku oznaczała wolność od dominacji jednego bądź kilku państw, które dzięki osiągniętej przewadze mogłoby prowadzić agresywne działania, nie napotykając skutecznego oporu. Przywrócenie równowagi było również niezbędne dla funkcjonowania porządku europejskiego. Równowaga sił była jego podstawą, gdyby jej zabrakło, stosunkami międzynarodowymi rządziłoby prawo silniejszego, co oznaczałoby powrót do czasów „Scytów bądź innych barbarzyńców" (Annual Register, 1772, s. 2). W ten sposób wojna stawała się narzędziem pokoju i środkiem obrony cywilizacji, które nie mogły istnieć w warunkach dominacji oraz anarchii na płaszczyźnie międzynarodowej.

Kolejna sytuacja, w której Burke dopuszczał wojnę, miała miejsce w trakcie rewolucji francuskiej. Na płaszczyźnie międzynarodowej widział ją jako zagrożenie dla systemu europejskiego i próbę sięgnięcia po hegemonię w skali 
kontynentu przez Francję (Burke, 1991, Third..., s. 339). Taki pogląd nawiązywał do często wyrażanych na Wyspach Brytyjskich w drugiej połowie XVII wieku i przez całe następne stulecie obaw przed „monarchią uniwersalną”, przez co rozumiano dominację jednego państwa nad większością kontynentu, a nawet nad jego całością. Powszechnie zgadzano się, że istnieje tego typu zagrożenie ze strony Francji. Wśród wyjątków znajdował się David Hume, który znacznie bardziej obawiał się brytyjskiego imperium handlowego, co jego zdaniem nadałoby brytyjskim rządom kolonialnym formę tyranii (Robertson, 1993, s. 371-372). Przyjmowano, że celem Francji jest powiększenie swego terytorium, a następnie narzucenie systemu politycznego: absolutyzmu i związanej z nim religii katolickiej. „Monarchia uniwersalna” stanowiła poważne zagrożenie dla całego porządku politycznego i społecznego na Wyspach Brytyjskich powstałego w wyniku „wspaniałej rewolucji” z lat 1688/89 (Pincus, 1995, s. 61-62). Burke nie uczestniczył w tej dyskusji, odniósł się do niej dopiero w końcowych latach swojej działalności. Dokonał jednak bardzo poważnej zmiany, która polegała na połączeniu polityki zagranicznej Francji z jej zmienioną w wyniku rewolucji sytuacją wewnętrzną. Znalazło to odzwierciedlenie na poziomie pojęć - zamiast „monarchii uniwersalnej” pojawiły się „imperium uniwersalne” i „rewolucja uniwersalna" (Burke, 1991, Third..., s. 340) - oraz na nadaniu im nowego znaczenia. Rewolucjonistów oskarżał nie tyle o dążenie do ekspansji terytorialnej, ale przede wszystkim o pragnienie zniszczenia całego istniejącego porządku międzynarodowego i wewnętrznego państw europejskich. Tym razem nie chodziło o zmianę formy rządów w obrębie znanych systemów władzy czy zastąpienie jednego odłamu chrześcijaństwa innym. Chodziło o ich całkowitą likwidację i stworzenie nowego ładu opartego na abstrakcyjnych zasadach (Burke, 1991, Second..., s. 267; Burke, 1991, Third..., s. 340; Burke, 1968, s. 191), a niezbędnym krokiem do tego było podważenie zasady równowagi sił (Burke, 1968, s. 161).

Burke wzywał władców europejskich do zbrojnego wystąpienia w jej obronie, ale był to tylko środek do znacznie ważniejszego celu. Burke odrzucał często akceptowaną przez współczesnych mu, między innymi Rousseau (Johnson, 1987, s. 186), hobbesowską koncepcję stosunków międzynarodowych, zgodnie z którą państwa dążą do realizacji egoistycznych interesów, a poprzez to znajdują się w stanie ciągłej rywalizacji (Anderson, 1993, s. 157, 164; Sheehan, 1996, s. 97). Wykpiwał ten pogląd już na początku kariery pisarskiej, co prowadziło jednak do pytania, w jaki sposób uniknąć takiej sytuacji (Burke, 2012, s. 12). Burke oczywiście dostrzegał obecność sprzecznych interesów państw, ale nie uważał opisanego stanu za nieuchronny. Sposobem było utrzymanie równowagi sił. 
Jednak równowaga sił nie była niezależnym od ludzi mechanizmem, który raz wprawiony w ruch, działał w samoczynny i ciągły sposób. Jak pisał, równowagę sił można przywrócić, ale nie będzie miała ona trwałego charakteru, jeśli nie zostaną również przywrócone „duch i zasady Europy” (Burke, 1968, s. 161). Dla funkcjonowania równowagi sił, a ostatecznie dla pokoju europejskiego niezbędna była akceptacja podstawowych wartości, na których opierała się cywilizacja europejska. „Wspólnota europejska” i pokój europejski nie znajdowały źródła we wspólnocie celów politycznych, oczywistym przecież było, że państwa miały różne interesy, ale we wspólnych wartościach, na które składały się religia chrześcijańska, rządy monarchiczne, zasady prawa rzymskiego i obyczaje ukształtowane w średniowieczu. Były to niewidzialne więzy, które łączyły ludzi znacznie silniej niż „dokumenty i pieczęcie” (Burke, 1991, First..., s. 247). To dzięki nim relacje między państwami nie miały charakteru hobbesowskiego. Wspólne wartości stanowiły podstawę do dialogu, bez którego pokój nie był możliwy: „Zanim ludzie zaczną załatwiać jakąkolwiek sprawę, potrzebują wspólnego języka i wspólnych zasad w oparciu o które mogą rozmawiać, w przeciwnym razie mamy do czynienia z niezrozumieniem i brakiem porządku" (Burke, 1991, Third..., s. 340).

Związany był z tym jednak sygnalizowany już problem suwerenności państw, który stanowił bardzo poważne wyzwanie dla osiemnastowiecznych myślicieli. Czy państwo, które naruszało podstawowe wartości, można było „ukarać” na drodze interwencji zbrojnej? Na początku stulecia zwolennicy „wiecznego pokoju” milcząco zakładali, że państwa dobrowolnie ograniczą suwerenność w zamian za korzyści wynikające z trwałego pokoju (Johnson, 1987, s. 177, 182-183). Jednak dla Rousseau sprawa była już dużo bardziej skomplikowana. W niechęci władców do rezygnacji z suwerenności widział jedną z głównych przeszkód w realizacji planów „wiecznego pokoju”. Propozycja, którą przedstawił, odzwierciedlała skalę problemu. Jedynym rozwiązaniem była rewolucja, która obaliłaby stary porządek, ale jak stwierdził, taka rewolucja mogłaby przynieść więcej szkód niż korzyści (Johnson, 1987, s. 191-192). Vattel zakładał, że państwa dysponują teoretycznie nieograniczoną suwerennością: „Z wolności i niepodległości narodów jasno wynika, że wszystkie narody mają prawo rządzić się, jak uznają za właściwe, i że żaden nie ma najmniejszego prawa mieszać się do rządów drugiego. Udzielność jest bez wątpienia najcenniejszym ze wszystkich praw, jakie naród posiada" (Vattel, 1958, s. 356). Uznał, że przyjęcie przez państwa ograniczeń prawnych związanych z wojną ma całkowicie dobrowolny charakter (Pitts, 2013, s. 135). Równocześnie jednak zakładał, że suwerenność podlega ograniczeniom. Państwa 
mają prawa do ingerencji zbrojnej po rozpoczęciu wojny domowej, wywołanej „nieznośną tyranią” (Vattel, 1958, s. 357) oraz ze względów religijnych, gdy „prześladowanie [innych wyznań ze strony władzy państwowej] dojdzie do niemożliwych ekscesów" (Vattel, 1958, s. 364). Burke zajął częściowo zbliżone stanowisko. Odpowiadając na pytanie o zakres suwerenności państw, dokonał rozróżnienia na stan, w którym władca łamał podstawowe wartości w dziedzinie stosunków wewnętrznych, nie zagrażając jednak porządkowi międzynarodowemu, oraz na stan, kiedy zasady były łamane i w związku z tym pojawiało się zagrożenie dla innych państw. Smutnym dla nas przykładem pierwszej sytuacji były działania dyplomatyczne Rosji, Prus, Wielkiej Brytanii i Danii na rzecz dysydentów w roku 1766, a następnie interwencja zbrojna Rosji. Burke uznał je za całkowicie uzasadnione, stwierdzając, że wina leżała po stronie Rzeczpospolitej, która nie przestrzega swych praw w stosunku do własnych mieszkańców. Identycznie traktował zabiegi dysydentów o poparcie zagranicy. Zabiegi te nie były formą zdrady, ale usprawiedliwioną prośbą o pomoc w sytuacji, kiedy ich własne państwo łamało przyjęte na siebie zobowiązania. Kolejnym uzasadnieniem dla ograniczenia suwerenności, o którym Vattel nie wspominał, było zapobieżenie przekształcenia się niepokojów wewnątrz Rzeczpospolitej, związanych ze sprawą dysydencką oraz elekcją Stanisława Augusta Poniatowskiego, w konflikt międzynarodowy (Annual Register, 1766, s. 11-14). Argument ten nawiązywał do rzymskiej zasady bliskości i sąsiedztwa, która, w interpretacji Burke’a, zezwalała państwu na podjęcie działań, gdy w sąsiednim kraju zachodziły zmiany, które zagrażały sytuacji międzynarodowej (Fidler, Welsh, 1999, s. 51). Druga sytuacja odnosiła się do zagrożeń stwarzanych przez rewolucyjną Francję dla kontynentu europejskiego. Zagrożenia te wynikały z rozwoju sytuacji wewnątrz Francji, jej agresywna polityka zewnętrzna odzwierciedlała ideologię rewolucyjną. Aby zlikwidować zagrożenia, nie wystarczało powstrzymanie ekspansji idei rewolucyjnych na zewnątrz, trzeba było zniszczyć je wewnątrz Francji. Wymagało to ingerencji w jej sprawy i Burke otwarcie nawoływał do obalenia reżimu rewolucyjnego (Burke, 1989, s. 305-308). Uzasadniał to wspomnianą obroną wspólnych wartości, bez których nie może istnieć pokój europejski, ale, podobnie jak w przypadku Rzeczpospolitej, także przywróceniem podeptanych przez rewolucjonistów praw mieszkańców królestwa Francji (Burke, 1967, s. 217-218). I w tym przypadku zabiegi przeciwników rewolucji o poparcie z zewnątrz traktował jako usprawiedliwione, aktywnie wspierając ich działania (Lock, 2006, s. 391-392). Przyjęcie przez Burke’a koncepcji, zgodnie z którą suwerenność państwa podlega ograniczeniom ze względu na prawa mieszkańców gwarantowane przez to państwo, 
otwiera drzwi do dyskusji dotyczącej poglądów Burke’a na temat praw człowieka i ich ochrony na gruncie międzynarodowym, koncepcji tak ważnej dla naszych czasów. Trzeba jednak podkreślić, że „prawa człowieka” w wersji Burke’a różniły się w zasadniczy sposób od obecnie dominujących interpretacji (Lock, 2006, s. $313-319)^{2}$.

Przemyślenia Burke’a, dotyczące pokoju europejskiego i sposobów jego zapewnienia, umykają - z jednym wyjątkiem - prostym ocenom. Ten wyjątek dotyczy ciągłości jego poglądów. Najczęściej o pokoju europejskim pisał w trakcie rewolucji francuskiej, ale wszystkie najważniejsze opinie na ten temat: pokój jako wartość, o którą należy ciągle zabiegać, nieuchronny charakter wojny, Europa jako wspólnota wartości, równowaga sił jako najlepszy sposób zapewnienia pokoju, ograniczone znaczenie prawa międzynarodowego w relacjach między państwami, były obecne już w jego wczesnych pracach. Burke połączył równowagę sił z prawem międzynarodowym, dodając do tego koncepcję Europy jako wspólnoty wartości. Połączył wojnę z pokojem, widząc w niej jeden ze sposobów na zapewnienie tego drugiego. Te połączenia były możliwe dzięki praktycznemu podejściu do polityki, zgodnie z maksymą, iż „nauka o rządzeniu jest praktyczna i ma służyć praktycznym celom" (Burke, 1994, s. 78). Było to możliwe także dzięki stanowisku, że o wartości poszczególnych koncepcji decydują „okoliczności”, które „czynią dany obywatelski i polityczny system dobroczynnym lub zgubnym dla rodzaju ludzkiego”. „Okoliczności” miały niewiele wspólnego z aktualnymi wydarzeniami. Przez „okoliczności” rozumiał historię, religię, kulturę, obyczaje, przesądy, prawa i często bardzo trudno dostrzegalne związki między nimi (Burke, 1994, s. 27). Przykładem wspomniana już „zawiść”, w której znajdował jedno z głównych źródeł wojen. Jednak na terenie cesarstwa „zawiść” między Austrią i Prusami odgrywała pozytywną rolę, Burke widział w niej gwarancję pokoju i bezpiecznej egzystencji mniejszych państw niemieckich (Annual Register, 1772, s. 4). Koncepcja „pokoju wieczystego” musiała wydawać mu się nie tylko naiwna, ale, biorąc pod uwagę, że w określonych sytuacjach dopuszczał wojnę, a nawet do niej zachęcał, błędna. W przeciwieństwie do Rousseau czy Kanta nie zakładał, że każda wojna jest zła. Jednak dzielił z nimi bardzo ważny pogląd o istnieniu systemu zbiorowego, choć inaczej rozumiał jego sens. Saint-Pierre, Rousseau czy Kant postulowali utworzenie systemu bezpieczeństwa zbiorowego, w którym państwa zrzekłyby się dużej części bądź całej suwerenności. Traktowali to jako warunek wstępny dla powstania takiego systemu i jego funkcjonowania. Burke postulował istnienie systemu, w którym państwa byłyby odpowiedzialne za obronę, także na drodze wojny, wspólnych, podstawowych wartości niezbędnych 
nie tylko dla zachowania pokoju, ale także przetrwania i rozwoju cywilizacji europejskiej. Ze zwolennikami kontrolowania wojen poprzez ograniczenia prawne łączyło go przekonanie, że wojen nie tylko nie da się całkowicie wyeliminować, ale że w pewnych sytuacjach są one niezbędne. Vattel dopuszczał wojnę przeciwko państwu, które dążąc do hegemonii, zagrażało równowadze sił (Vattel, 1958, s. 355-356). Różniły ich jednak poglądy na temat systemu europejskiego. Vattel przyjmował, że taki system złożony jest $\mathrm{z} \mathrm{w}$ pełni niezależnych państw, a ich zobowiązania wobec wspólnoty wiążą się z obroną własnych interesów, które polegają na „utrzymywaniu porządku i obronie wolności” (Tuck, 2001, s. 191-194)33. Jak mogliśmy zauważyć, podstawą systemu europejskiego według Burke’a nie były interesy poszczególnych państw, które według Vattela szczęśliwie znajdowały wspólny mianownik w trosce o pokój i wolność, ale wspólne wartości. Różnili się też poglądami na temat roli prawa. Vattel uważał, że miało ono pierwszorzędne znaczenie dla ograniczenia wojen (Johnson, 1987, s. 201). Burke mógł stwierdzić, że kluczowa dla sytuacji europejskiej równowaga sił na obszarze cesarstwa jest oparta o „prawo międzynarodowe czy też wiele praw” (Burke, 1991, Thoughts..., s. 350), ale znacznie częściej jako element niezbędny dla równowagi sił i pokoju na kontynencie wskazywał wspólne wartości znajdujące swe źródło w chrześcijaństwie i dziedzictwie przeszłości. Ten element z kolei zbliżał go do tych zwolenników „wiecznego pokoju”, a był wśród nich Rousseau (Johnson, 1987, s. 190), którzy zwracali uwagę na wspólne dziedzictwo kulturowe i wykorzystywali je jako argument na rzecz swoich planów. Jednak - i tu kolejne przeciwieństwo - Burke nie zakładał, że to dziedzictwo będzie wystarczającą zaporą przed konfliktami zbrojnymi.

Sytuacja, w której Burke’a tak wiele różniło, ale też łączyło ze zwolennikami koncepcji „wiecznego pokoju” oraz wojny sprawiedliwej, wskazuje, że przeprowadzenie wyraźnego podziału między nim a obydwoma „tradycjami moralnymi" cywilizacji Zachodu nie jest możliwe. Każe to zastanowić się nad przyczynami różnic i podobieństw. Czy wynikały one z fundamentalnych różnic poglądów, na przykład na temat natury człowieka, czy też przyjęcia odmiennych perspektyw? Rozważania Kanta, Rousseau i Vattela miały charakter teoretyczny, a dla zilustrowania swoich poglądów sięgali oni po mniej lub bardziej odległe w czasie przykłady. Burke traktował o czasach współczesnych, musiał przełożyć teoretyczne założenia na praktykę życia politycznego. Co w końcu oznaczała „nieznośna tyrania” bądź „niemożliwe ekscesy” w relacjach między państwami? Odpowiedzi na pytania o źródła podobieństw i różnic poglądów wymagają 
badań porównawczych, które poza wzbogaceniem wiedzy mogą prowadzić do zaskakujących wniosków.

\section{BibLIOGRAFIA:}

Anderson, M.S. (1993). The Rise of Modern Diplomacy 1450-1919. London: Longman. Archibugi, D. (1992). Models of International Organization in Perpetual Peace Projects. Review of International Studies, 18, 295-317.

Armitage, D. (2012). Foundations of Modern International Thought. Cambridge: Cambridge University Press.

Blaszke, M. (2016). De Saint-Pierre - Projekt wiecznego pokoju w Europie. Filo - Sofija, $35,95-109$.

Boucher, D. (1991). The Character of the History of Philosophy of International Relations and the Case of Edmund Burke. Review of International Studies, 2, 127-148.

Boucher, D. (1998). Political Theories of International Relations. From Thucydides to the Present. Oxford: Oxford University Press.

Bourke, R. (2012). Burke, Enlightenment and Romanticism. W: D. Dwan, C.J. Insole (red.). The Cambridge Companion to Edmund Burke. Cambridge: Cambridge University Press.

Bourke, R. (2015). Empire \& Revolution. The Political Life of Edmund Burke. Princeton: Princeton University Press.

Buchner, W. (2017). Ład utracony. Szkice z historii myśli politycznej. Kraków: Wydawnictwo Arcana.

Burke, E. (1981). Policy of Making Conquests for the Mahometans. W: P.J. Marshall, W.B. Todd (red.). The Writings and Speeches of Edmund Burke, Vol. 5: India: Madras and Bengal: 1774-1785. Oxford: Clarendon Press.

Burke, E. (1989). Letter to a Member of the National Assembly. W: L.G. Mitchell, W.B. Todd (red.). The Writings and Speeches of Edmund Burke, Vol. 8: The French revolution: 1790-1794. Oxford: Clarendon Press.

Burke, E. (1991). First Letter on a Regicide Peace 1796. W: R.B. McDowell, W.B. Todd (red.). The Writings and Speeches of Edmund Burke, Vol. 9: The Revolutionary War, 1794-1797; II: Ireland. Oxford: Clarendon Press.

Burke, E. (1991). Second Letter on a Regicide Peace 1796. W: R.B. McDowell, W.B. Todd (red.). The Writings and Speeches of Edmund Burke, Vol. 9: The Revolutionary War, 1794- 1797; II: Ireland. Oxford: Clarendon Press.

Burke, E. (1991). Third Letter on a Regicide Peace 1797. W: R.B. McDowell, W.B. Todd (red.). The Writings and Speeches of Edmund Burke, Vol. 9: The Revolutionary War, 1794-1797; II: Ireland. Oxford: Clarendon Press.

Burke, E. (1991).Thoughts on French Affairs 1791. W: L.G. Mitchell, W.B. Todd (red.). The Writings and Speeches of Edmund Burke, Vol. 8: The French Revolution: 1790-1794. Oxford: Clarendon Press.

Burke, E. (1994). Rozważania o rewolucji we Francji. Kraków: Społeczny Instytut Wydawniczy Znak. 
Burke, E. (2012). O duchu i naturze rewolucji. Kraków: Ośrodek Myśli Politycznej.

Butterfield, H. (1966). The Balance of Power. W: H. Butterfield, M. Wight (red.). Diplomatic Investigations. Essays in the Theory of International Politics. London: George Allen \& Uniwin.

Clark, J.C.D. (2007). The Enlightenment, Religion and Edmund Burke. Studies in Burke and His Time, 21, 9-38.

Cobban, A., Smith, R.A. (red.). (1967). The Correspondence of Edmund Burke. Volume VI July 1789-December 1791. Cambridge: Cambridge University Press.

Fidler, D.P., Welsh, J.M. (1999). Empire and Community. Edmund Burke's Writings and Speeches on International relations. Boulder: Westview Press.

Fuller, J.F.C. (1972). The Conduct of War 1789-1961. London: Eyre Methuen.

Grobis, J. (2003). Dezyderat czy warunek? Formułowanie teoretycznych podstaw „równowagi sił” czasów nowożytnych. Przegląd Nauk Historycznych, 2(4), 29-65.

Hampsher-Monk, I. (2005). Edmund Burke's Changing Justification for Intervention. The Historical Journal, 1, 65-100.

Hanczewski, P. (2017). Stare i nowe problemy z Edmundem Burkiem. Kwartalnik Historyczny, 3, 569-590.

Hanczewski, P. (2018). "When Liberty and Order Kiss": Edmund Burke and the History Articles in the Annual Register. Studies in Burke and His Time, 27, 56-86.

Harle, V. (1990). Burke the International Theorist - or the War of the Sons of Light and the Sons of Darkness. W: V. Harle (red.). European Values in International Relations. London: Pinter Publishers.

Hassner, P. (2013). Sovereignty, Morality, and History: The Problematic Legitimization of Force in Rousseau, Kant, and Hegel. W: S. Recchia, J. M. Welsh (red.). Just and Unjust Military Intervention. European Thinkers from Vitoria to Mill. Cambridge: Cambridge University Press.

Hurrell, A. (1996). Vattel: Pluralism and Its Limits. W: I. Clark, I.B. Neumann (red.). Classical Theories of International Relations. London: Macmillan Press.

Johnson, J.T. (1987). The Quest for Peace. Three Moral Traditions in Western Cultural History. Princeton: Princeton University Press.

Johnson, J.T. (2011). Ethics and the Use of Force. Just War in Historical Perspective. Farnham: Ashgate Publishing Limited.

Kant, I. (2011). Metafizyka moralności. W: W. Włoch (red.). Immanuel Kant. Dzieła zebrane. Tom V. Toruń: Wydawnictwo Naukowe Uniwersytetu Mikołaja Kopernika.

Keller, A. (2006). Justice, Peace and History: A Reappraisal. W: P. Allan, A. Keller (red.). What is a Just Peace?. Oxford: Oxford University Press.

Lock, F.P. (2006). Edmund Burke, Volume II: 1784-1797. Oxford: Oxford University Press.

Marshall, P.J., Woods, J.A. (red.). (1968). The Correspondence of Edmund Burke. Volume VII January 1792-August 1794. Cambridge: Cambridge University Press.

Marulewska, K. (2005). Idea “wiecznego pokoju” Kanta a współczesny porządek międzynarodowy. Dialogi Polityczne, 5-6, 173-185. 
McKay, D., Scott, H.M. (1983). The Rise of the Great Powers 1648-1815. London: Longman.

O'Neill, D.I. (2016). Edmund Burke and the Conservative Logic of Empire. Berkeley: University of California Press.

Pincus, S. (1995). The English debate over universal monarchy. W: J. Robertson (red.). A Union for Empire. Political Thought and the British Union of 1707. Cambridge: Cambridge University Press.

Pitts, J. (2013). Intervention and sovereign equality: legacies of Vattel. W: S. Recchia, J. M. Welsh (red.). Just and Unjust Military Intervention. European Thinkers from Vitoria to Mill. Cambridge: Cambridge University Press.

Robertson, J. (1993). Universal Monarchy and the Liberties of Europe: David Hume's Critique of an English Whig Doctrine. W: N. Phillipson, Q. Skinner (red.). Political Discourse in Early Modern Britain. Cambridge: Cambridge University Press.

Ruddy, F.S. (1969). International Law and the Enlightenment: Vattel and The $18^{\text {th }}$ Century. The International Lawyer, 4, 839-858.

Serejski, H. (2009). Europa a rozbiory Polski. Warszawa: Wydawnictwo Naukowe PWN. Sheehan, M. (1996). The Balance of Power. History and Theory. London: Routledge.

Souleyman, E.V. (1941). The Vision of World Peace in Seventeenth and Eighteenth-Century France. Port Washington: Kennikat Press.

Sutherland, L.S. (red.). (1960). The Correspondence of Edmund Burke. Volume II July 1768-June 1774. Cambridge: Cambridge University Press.

The Annual Register, For the Year 1759. (1759).

The Annual Register, For the Year 1761. (1761).

The Annual Register, For the Year 1762. (1762).

The Annual Register, For the Year 1763. (1763).

The Annual Register, For the Year 1764. (1764).

The Annual Register, For the Year 1766. (1766).

The Annual Register, For the Year 1772. (1772).

The Annual Register, Of the Year 1760. (1760).

Tuck, R. (2001). The Rights of War and Peace: Political Thought and the International Order from Grotius and Kant. Oxford: Oxford University Press.

Vattel, E. (1958). Prawo narodów. T. I. Warszawa: Państwowe Wydawnictwo Naukowe.

Vincent, R.J. (1984). Edmund Burke and the Theory of International Relations. Review of International Studies, 3, 205-218.

Welsh, J.M. (1995). Edmund Burke and International Relations. The Commonwealth of Europe and the Crusade against the French Revolution. Basingstoke: Macmillan.

Welsh, J.M. (1996). Edmund Burke and the Commonwealth of Europe: The Cultural Bases of International Order. W: I. Clark, I.B. Neumann (red.). Classical Theories of International Relations. London: Macmillan Press.

Welsh, J.M. (2013). Edmund Burke and Intervention: Empire and Neighborhood. W: S. Recchia, J.M. Welsh (red.). Just and Unjust Military Intervention. European Thinkers from Vitoria to Mill. Cambridge: Cambridge University Press. 
Wight, M. (1966). The Balance of Power. W: H. Butterfield, M. Wight (red.). Diplomatic Investigations. Essays in the Theory of International Politics. London: George Allen \& Uniwin.

Wight, M. (1966). Why is there no International Theory? W: H. Butterfield, M. Wight (red.). Diplomatic Investigations. Essays in the Theory of International Politics. London: George Allen \& Uniwin.

Williams, H., Booth, K. (1996). Kant: Theorist Beyond Limits. W: I. Clark, I.B. Neumann (red.). Classical Theories of International Relations. London: Macmillan Press. 